\title{
ПРОЯВИ НЕКЛІНІЧНОГО НАРЦИСИЗМА: ПОШУК ІНДИВІДУАЛЬНИХ ВІДМІННОСТЕЙ
}

\author{
Ольга Саннікова \\ доктор психологічних наук, професор, \\ завідувачка кафедри загальної та диференціальної психології \\ Д3 «Південноукраїнський національний педагогічний університет \\ імені К.Д. Ушинського» \\ 65020, Україна, м. Одеса, вул. Фонтанська Дорога, 4 \\ osanniland@gmail.com, https://orcid.org/0000-0003-3961-2103
}

Researcher ID: I-5139-2018

\begin{abstract}
Анотація
Запропонована стаття грунтується на досвіді багатьох років роботи автора над проблемою індивідуальних відмінностей осіб, які відрізняються індивідуально-психологічними особливостями емоційності. Розглядаються особливості деяких небажаних соціальних проявів, що відносяться до нарцисичних тенденцій, до крайніх (субклінічних) варіантів «норми». «Вільний індивідуалізм», що став популярним останні роки у суспільстві, не тільки призводить до порушень спілкування, порушень міжособистісних відносин, впливає на успішність діяльності, а й сприяє розвитку особистісної організації як нарцисичної. Саме тому актуальним стає теоретико-методологічне обгрунтування проблеми нарцисизма, вивчення його психологічних виявів, індивідуальних варіацій ознак цього феномена. Підгрунтям для пошуку індивідуально-типових особливостей нарцисизма нами обрано емоційність, яка розглядається як стійка схильність до переживання емоцій певної якості (знак і модальність домінуючих емоцій). Мета статті - виклад та обговорення результатів дослідження індивідуально-психологічних особливостей неклінічного нарцисизма в осіб, котрі різняться за емоційністю. Виявлена наявність від'ємних значущих зв'язків між емоційною модальністю «Радість» і більшістю показників нарцисизма; у той же час модальності «Гнів» «Страх», «Печаль» корелюють із показниками нарцисизма переважно додатно. Розглянуті профілі нарцисизма осіб, що різняться за емоційністю (стійке домінування однієї з емоційних модальностей); вивчені «психологічні портрети» осіб, які схильні до нарцисичних тенденцій, і його специфіка в представників мономодальних типів емоційності; встановлені відмінності в структурі й проявах нарцисизма між представниками різних типів емоційності. Підтверджено припущення про те, що індивідуальна своєрідність нарцисичних рис у межах психічної норми, варіативність їх індивідуальних композицій (якісно-кількісна комбінація компонентів нарцисизма) зумовлені ступенем домінування певної емоційної модальності.
\end{abstract}

Ключові слова: нарцисизм, композиції нарцисизма, нарцисичні тенденції, емоційність, індивідуально-психологічні композиції нарцисизма.

\section{Вступ}

У сучасному суспільстві в період глобальних і масштабних соціокультурних змін збільшується прагнення до «вільного індивідуалізму», до небажаних соціальних проявів крайніх (субклінічних) варіантів «норми», зокрема, до наростання нарцисичних тенденцій. 
Цим можна пояснити значне підвищення наукового й практичного інтересу до психологічних конструктів, які формують певний світогляд, часом дискредитуючи моральні орієнтири.

Останнім часом дискутується проблема «Темної тріади» особистості (Егорова \& Ситникова, 2014; Svindseth, Sorebo, Nottestad, Roaldset, Wallin \& Dahl, 2009), до складу якої входить нарцисизм. У процесі розробки нарцисичної проблематики збільшується потреба в емпіричних дослідженнях нарцисизма як психічного феномена.

Важливо відзначити, що психоаналітичну концепцію нарцисизму запропонував 3. Фрейд ще в 1914 р. Нарцисизм він розумів як концентрацію інтересу людини винятково на собі. Цей специфічний стан 3. Фрейд розглядав і як особистісний, і як клінічний феномен (Фрейд, 2006). Пізніше цей феномен уточнюється й визначається і як деякий стійкий тривалий стан, що виник на основі викривлення способів регуляції уявлень особистості про себе, і як особистісна риса, яка характеризується, у першу чергу, «демонстрацією грандіозності» (Клепикова, 2014; Корнилова, Корнилов, Чумакова \& Талмач, 2015). У психології індивідуальних відмінностей нарцисизм («неклінічний нарцисизм») розглядається як стабільна риса особистості, що варіює в межах норми, що й впливає на особливості міжособистісних відносин і успішність діяльності (Залуцкая, 2011). Однак, дотепер нарцисизм як поняття не має загальноприйнятого визначення в сучасній психології, що свідчить не тільки про інтерес різних наук до цього явища, про різноманітність підходів до його вивчення, але й про складність і неоднозначність самого феномена.

У літературі $\epsilon$ інформація про пошук індивідуальних відмінностей у проявах нарцисизма (Саннікова, \& Децик, 2018); вивчається зв'язок нарцисизму із труднощами ідентифікації емоцій, з низькою емпатію та алекситимією (Jonason, Jones \& Krause, 2013); 3 виразною демонстративністю, упевненістю в перевазі над оточуючими, потребою завжди перебувати в центрі уваги (Morf \& Rhodewalt, 2009); у зв'язку з авантюрністю як рисою особистості (Меленчук, 2015; Меленчук \& Бєлєнцова, 2019); з самоприйняттям (Гордієнко, 2017); недоброзичливістю, ворожістю й, що особливо для нас важливо, з емоційною сферою особистості, зокрема, з агресивністю й агресивною поведінкою у випадках виникнення найменшої уявної або реальної загрози (Jones \& Paulhus, 2010); 3 емоційною самоефективністю тощо.

Відомо, що нарцисизм є самостійним конструктом Темної тріади особистості, що не зводиться до двох інших ії складових - психопатії й макіавеллізму. Уперше термін «Темна тріада» як синдром певних властивостей, що умовно відносяться до «норми», точніше до іiі крайніх субклінічних варіантів, запропонували й описали канадські дослідники Delroy Paulhus, Kevin Williams (2002). Ця тріада, в структуру якої входять неклінічний нарцисизм, неклінічна психопатія й макіавеллізм, характеризує негативні сторони особистості: зневажливе ставлення до інших людей, до загальноприйнятих норм поведінки; прояв егоцентризму, егоїзму, недоброзичливості, емоційної холодності, почуття власної переваги тощо. Необхідно зауважити, що в «пантеон темних особистостей» нездавна Erin E. Buckels1, Daniel N. Jones, Delroy L. Paulhus (2010) додали четвертий член цього комплексу - «повсякденний садизм», якого, також, як й психопатії, й макіавеллізму, ми не будемо торкатися в рамках цієї статті. Історія формування уявлень про зміст характеристик Темної тріади та їі місце в структурі базових рис особистості докладно представлені в роботах М.С. Сгорової та М.А. Ситникової (2014). Фактично негативні риси, значення яких раніше недооцінювалося й навіть ігнорувалося базовими структурами особистості, як спеціальний предмет дослідження вперше включається в коло інтересів учених. Разом з тим, ще Е. Фромм 
відзначав, що протягом усього свого життя людина, деякою мірою, нарцисична, навіть при нормальному іiі розвитку (Фромм, 2010).

Як підстава для пошуку індивідуальних відмінностей у проявах нарцисизма ми обрали емоційність, яку розглядаємо як стійку властивість індивідуальності. Співвіднесенню нарцисизма й емоційності передували наступні міркування.

По-перше, в «Моделі особистості НЕХАСО» (факторна теорія особистості) один із шести вимірів або факторів особистості - це «Емоційність». У моделі «Великої П'ятірки» виділений фактор «Емоційна стабільність». Обидва ці фактора в багатьох дослідженнях виявляють зворотну взаємозалежність між собою (збільшення значень одного фактора приводить до зменшення іншого) й, що для нас важливо, корелюють із нарцисизмом, хоч $\mathrm{i}$ неоднозначно (протилежним чином), що свідчить про взаємозв'язок нарцисизма з емоційною сферою особистості.

По-друге, в самій структурі нарцисизма присутні риси, що характеризують особливості афективної сфери особистості (див. нижче), що переконує в правильності вибору напрямку дослідження. При цьому, необхідно особливу увагу приділити поняттю «емоційність», тому що від цього залежить розуміння й нашої ідеї, й отриманих результатів дослідження.

В «Моделі особистості НЕХАСО» фактор емоційність (Е) трактується як емоційна надчутливість, сентиментальність, страх, тривожність, уразливість. У моделі «Великої П'ятірки» четвертий біполярний фактор (нейротизм - емоційна стриманість), також містить у собі характеристики афективної сфери особистості. Емоційність проявляється в підвищеній чутливості до середовищних впливів (особливо в стресових ситуаціях), у схильності до тривоги й депресії, напруженості, самокритичності. Емоційна стриманість, навпаки, характеризує людину як схильну виявляти лагідність, неквапливість і самодостатність. По суті, в цих факторах наведені різнорівневі риси емоційної сфери (в основному, негативні емоції), що характеризують іiі динамічну сторону (неквапливість, стриманість) і риси характеру (безтурботність, самодостатність, комфортність тощо).

Наше розуміння емоційності опирається на роботи В.Д. Небиліцина (2000), А.Ю. Ольшанникової (1978). Емоційність розглядається як одна 3 найважливіших, поряд із психічною активністю, стійких характеристик індивідуальності, яка є комплексом властивостей, що охоплює: формально-динамічні ознаки емоцій (сила, інтенсивність, тривалість, швидкість протікання, зміни тощо); якісні характеристики, які несуть інформацію про модальність (паттерни емоцій «радість», «гнів», «страх» і «сум, печаль») і знак емоційного переживання (додатний «+» $\mathrm{i}$ від'ємний «-»); змістові характеристики емоиійності, що полягають у самому об'єкті переживань. Параметри, які характеризують якість емоційного переживання, а, саме, його модальність і знак домінуючих емоцій, є найважливішими в сукупності всіх ознак емоційності (Небылицин, 2000; Ольшанникова, 1978; Санникова, 2003, 2014; Sannikova, Sannikov \& Husak, 2020).

Отже, метою статті $є$ виклад результатів вивчення індивідуально-психологічних особливостей неклінічного нарцисизмуа в осіб, які різняться за емоційністю. Для реалізації мети необхідно розв'язати наступні завдання дослідження: 1) виявити й вивчити специфіку взаємозв'язку між показниками емоційності й нарцисизма; 2) виявити комбінації якісних характеристик емоційності (типи), що стійко виявляються; 3) виявити представників цих типів i вивчити властиву їм специфіку прояву неклінічного нарцисизма. Приступаючи до дослідження, ми припустили, що індивідуальна своєрідність нарцисичних рис у межах психічної норми, варіативність їх індивідуальних комбінацій (якісно-кількісна комбінація 
показників нарцисизму) зумовлені ступенем домінування тієї або іншої емоційної модальності.

\section{Методи дослідження}

Для вивчення нарцисизма використовувався «Тест оцінки нарцисизма» - клінікопсихологічна тестова методика, яка розроблена F.-W. Deneke i B. Hilgenstock. Ця методика адаптована в 2003 році в Національному медичному дослідницькому центрі психіатрії та неврології імені В.М.Бехтєрєва такими вченими як Н.М. Залуцька та А.Я. Вукс під керівництвом В.Д. Вида. Тест складається з 163 пунктів і містить у собі 18 шкал (Залуцкая, 2003). За допомогою методики діагностуються наступні показники: H1 - неспроможне Self, Н2 -втрата контролю емоцій і спонукань, Н3 - дереалізація, деперсоналізація, Н4 - базисний потенціал надії, H5 - Незначне Self, H6 - негативне тілесне Self, H7 - соціальна ізоляція, Н8 архаїчний відхід, Н9 - грандіозне Self, H10 - прагнення до ідеального Self-Об'єкту, H11 - прагнення похвал і підтвердження, Н12 - нарцисична злість, Н13 - ідеал самодостатності, Н14 - знецінювання об'єкта, Н15 - ідеал цінностей, Н16 - симбіотичний захист Self, H17 - іпохондричний захист від тривоги, Н18 - нарцисична вигода від хвороби, Н19 - загальний показник нарцисизма. Докладна характеристика домінуючих шкал розкрита нижче при описі профілів нарцисизма.

Дослідження емоційності проводилося за допомогою «Психодіагностичного чотирьохмодальнісного тест-опитувальника емоційності» (Санникова, 2003), спрямованого на вивчення іiі якісних показників, що характеризують стійку (неклінічну) схильність до переживання: емоцій паттерна «Радість» (Р - радісний настрій, почуття задоволеності світом, людьми, собою); емоцій паттерна «Гнів» (Г - дратівливість, нестриманість, схильність до брутальності, злості тощо); емоцій паттерна «Страх» (С - боязкість, очікування небезпек, настороженість, острах усього нового, невідомого, тривожність тощо); емоцій паттерна «Сум, печаль» (П - знижений настрій, відчуття непевності, втрати, пригніченості, схильність до депресивних станів, навколишній світ сприймається як похмурий, «пофарбований» у сірий колір тощо).

Дослідження проводилося на базі Південноукраїнського Національного педагогічного університету імені К.Д. Ушинського. У ньому брали участь 110 осіб у віці від 18 до 30 років. Обробка отриманих даних здійснювалася за допомогою кількісного (кореляційного) і якісного (методи асів, профілів) аналізів даних, у результаті чого були виявлені загальні закономірності й індивідуальні відмінності в проявах неклінічного нарцисизма.

\section{Результати та дискусії}

Результати, що отримані в ході кореляційного аналізу показників емоційності й нарцисизма показують наявність значної кількості зв'язків, що свідчить про правочинність зіставлення якісних характеристик емоційності з показниками нарцисизма (див. табл.1).

Аналіз табл. 1, по-перше, виявляє значну кількість зв'язків, що свідчить про правочинність зіставлення якісних характеристик емоційності з показниками нарцисизма. 
Таблиия 1

Значущі кореляційні зв'язки між якісними показниками емоційності й характеристиками нарцисизма

\begin{tabular}{|c|c|c|c|c|c|c|c|c|}
\hline \multirow[t]{2}{*}{ Емоиійність } & \multicolumn{8}{|c|}{ Показники наричисизма } \\
\hline & $\mathrm{H} 1$ & $\mathrm{H} 2$ & $\mathrm{H} 3$ & $\mathrm{H} 4$ & H5 & H6 & $\mathrm{H} 7$ & H9 \\
\hline Р радість & $-259 * *$ & & $-199 *$ & $210^{*}$ & $-273 * *$ & $-322 * *$ & $-335 * *$ & $234^{*}$ \\
\hline \multirow[t]{2}{*}{ Г гнів } & & & & & & & & \\
\hline & $310 * *$ & $269 * *$ & $217 *$ & & $364 * *$ & $263 * *$ & $279 * *$ & \\
\hline С страх & $277 * *$ & $265 * *$ & & & $242 *$ & & $370 * *$ & \\
\hline \multirow[t]{3}{*}{ П сум } & $368 * *$ & $284 * *$ & $217 *$ & $-219 *$ & $375 * *$ & $311 * *$ & $280 * *$ & $-216^{*}$ \\
\hline & \multicolumn{8}{|c|}{ Показники нариисизма } \\
\hline & H10 & H11 & H12 & H14 & H16 & H17 & H18 & H19 \\
\hline $\mathrm{P}$ & $198^{*}$ & & $-200 *$ & $-330 * *$ & & & $-299 * *$ & $-199 *$ \\
\hline$\Gamma$ & $237 *$ & $315 * *$ & $439 * *$ & $319 * *$ & $343 * *$ & $387 * *$ & $319 * *$ & $398 * *$ \\
\hline $\mathrm{C}$ & & & $196 *$ & & & & & $219 *$ \\
\hline$\Pi$ & & $196^{*}$ & $332 * *$ & $371 * *$ & $256^{*}$ & $292 * *$ & $299 * *$ & $390 * *$ \\
\hline
\end{tabular}

Примітки: 1) $N=110$; 2) нулі й коми опущені; 3) позначення “*» показує зв'язок на рівні $5 \%(\rho \leq 0,05)$, позначення «**» - на рівні $1 \%(\rho \leq 0,01)$; 4) умовні скорочення показників подані в тексті; 5) деякі показники нариисизма ( H8, H13, H15) у табл. 1 не представлені, тому щуо значущих зв'язків з показниками емоційності не виявлено (лище на рівні тенденцій).

Отримані коефіцієнти кореляцій розділилися на два полюси - виявлені значущі додатні зв'язки показників нарцисизма з модальностями Г (гнів), С (страх), П (печаль, сум) і від'ємні 3 показником Р (радість). Така картина характеризує протилежність полюсів емоційності, 3 одного боку, модальність Р (носій додатного знака), з іншого боку - модальності Г, С и П (носії від'ємного знака емоцій). У цілому, можна стверджувати, що емоції Г (гнів), 3 (страх) і П (сум) прямо пропорційно взаємозалежні з більшістю показників нарцисизма, а модальність Р зворотно пропорційно. Іншими словами, прояв нарцисичних тенденцій супроводжуються переживаннями «зафарбованими» негативними емоціями, у той час як модальність Р і емоції цього паттерну зменшують, гальмують ознаки нарцисизма.

Можна припустити, що особи з негативною емоційною диспозицією більшою мірою схильні до нарцисизма. Для перевірки цього припущення й, відповідно до мети дослідження, ми вивчили індивідуально-психологічні особливості неклінічного нарцисизма в осіб, що різняться за емоційністю. Для цього на підставі даних, отриманих за допомогою тестопитувальника емоційності (Саннікова, 2003), з наступним застосуванням методу «асів», були виділені групи обстежених, які характеризуються крайнім домінуванням однієї з емоційних модальностей: P (радість, N=15), Г (гнів, N=11), 3 (страх, N=9), П (сум, N=12) на тлі слабкого виразу інших.

Особливості нарцисизма виявлялися за допомогою методу профілів, представлених на рис. 1. На осі ОХ відзначені показники нарцисизма, на осі OY - процентилі. Попередньо сирі бали були переведені в процентілі, що спричинено необхідністю врахування всіх емпіричних розподілів (по кожній шкалі) та їх зведення до нормальної моделі при відсутності тестових норм. 


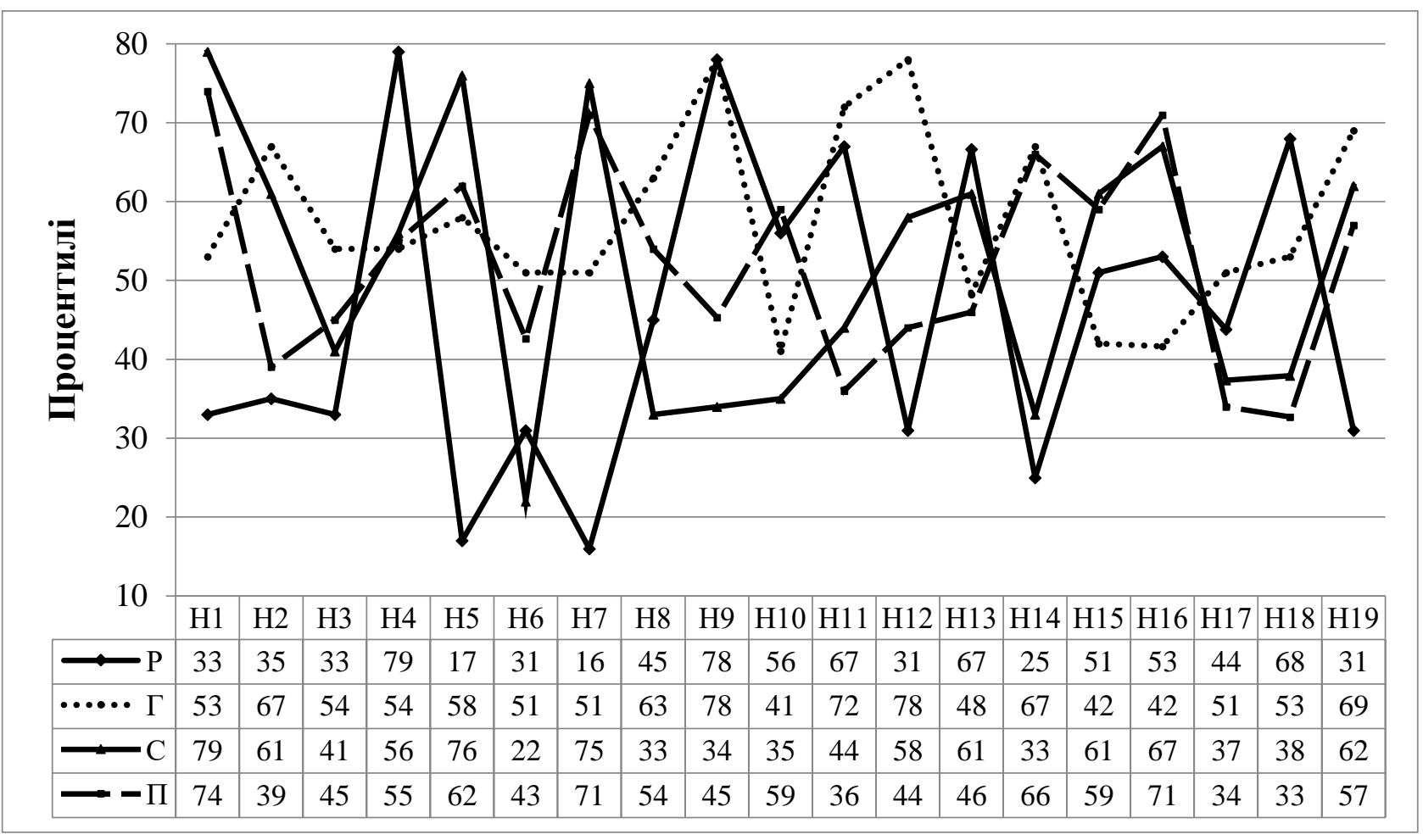

\section{Рис. 1. Профіль нарцисизма груп обстежених з різною емоційною диспозицісю}

Примітка: скорочення показників нариисизмп надано в тексті статті (див. вище).

Профілі містять усереднені значення кожного показника всіх представників кожної групи. Важливо відзначити, що вкрай високих і вкрай низьких значень у профілях не виявлено, що свідчить про відсутність у представників цих груп схильності до нарцисичної патології. Проаналізуємо спочатку профіль нарцисизма в кожній групі обстежених окремо, потім порівняємо їх між собою. Важливо відзначити, що опис психологічних характеристик різних груп обстежених спирався на концепцію лише авторів методики, що діагностує нарцисизм.

Група Р. Представникам цієї групи властива установка на реалізацію своїх особистісних ресурсів всупереч можливим труднощам, оптимізм, віра у власні сили в будьяких ситуаціях, любов до себе, надія на зміну ситуації на кращу, надія на можливість подолання кризи за рахунок мобілізації власних резервів опору й сили (H4+ базисний потенціал надії). Таким особам властива висока соціабільність. Вони легко справляються із соціально небезпечними ситуаціями, соціально відкриті, не приховують своїх почуттів перед оточуючими, легко встановлюють соціальний контакт, ефективні в розпізнаванні тієї позитивної оцінки, яку їм дають оточуючі, соціально не напружені, що полегшує оточуючим установлення контакту з ними (Н7 - соціальна ізоляція). «Радісники» мають досить високу самооцінку, впевнені в собі й у своїй цінності (H5 - незначне Self). Високо оцінюють свої лідерські якості, мають оптимістичну установку на свої природні дані, резервні потенціали. При цьому вони адекватно сприймають межі своїх здатностей, а також можливу перевагу інших людей над собою (H9+ грандіозне Self).

Група Г (схильність до переживання емоцій партерна гнів). Представники цієї групи мають досить високу самооцінку, високу установку на досягнення успіху, вірять у свою соціальну ефективність. Однак, болісно сприймають межі своїх здатностей і привабливості, визнають перевагу інших людей над собою, про що свідчить параметр грандіозне Self (H9+). «Гнівливіки» (Гнів) часто відчувають негативні емоції, що пов'язані з образою, соромом, 
приниженням, розчаруванням, що може викликати в них відповідну лють і жагу до помсти. При цьому відповідна агресія все більш втрачає свою захисну, конструктивну функцію, кількісно зростаючи і якісно трансформуючись у деструктивну агресію. Це може включити неконтрольоване індивідом порочне коло дестабілізації Self-Системи. Однак, при конструктивному варіанті агресії, контроль поведінки, афекту й спонукань відбувається, як стверджують автори даного варіанта методики (Залуцкая, 2003; Корнилова, Корнилов, Чумакова \& Талмач 2015), «стабілізація Self-Системи, що захищає особистість від нарцисичного шоку й втрати власної цінності» (Н12+ нарцисична злість). Саме тому, на наш погляд, таким особистостям часто необхідна похвала, що дає їм підтвердження прийняття себе оточуючими. Вони прагнуть бути в центрі уваги й дратуються, якщо їх ігнорують (Н11+ прагнення похвал і підтвердження).

Група С (схильність до остраху). Для представників цієї групи характерний стан безпорадності, відсутність цілепокладання, негативна самооцінка, порушення самоорганізації й саморегуляції поведінки, почуття власного безсилля, яке іноді проявляється у фізичній агресії проти себе, переживання інтенсивного страху, відчуття неконтрольованої тривоги, деструктивних спонук зі спрямованістю агресії проти себе (H1+ неспроможне Self). Вони схильні перебільшувати негативні оцінки оточуючих, часто переживають почуття сорому й непевності, мають сумніви в цінності власної особистості й постійно переживають страх розкриття оточуючими своєї малоцінності. При цьому, такі особи все-таки досягають певного рівня стабілізації (H5+ незначне Self). Схильним до страху («страховикам») також властиво соціальне уникнення, бар'єри спілкування, вони часто не справляються 3 небезпечними соціальними ситуаціями, не схильні розкривати свої почуття оточуючим, напружені, в спілкуванні з незнайомими людьми переживають дискомфорт, тому уникають соціальних контактів з метою захисту від нарцисичної травматизації (Н7+ соціальна ізоляція).

Група П. Схильним до суму (представники групи П - «осмутненим»), як і представникам групи С, властиві бар'єри спілкування, небажання спілкуватися 3 малознайомими людьми. Вони схильні до самотності, часто розчаровуються в людях. У принципі, ці особи не бояться соціального контакту й уміють при необхідності на нього відповісти, але для представників цієї групи характерна власна вибірковість у виборі партнера, що дозволяє їм знаходити адекватну дистанцію в спілкуванні (Н7+ соціальна ізоляція). Представникам групи П також властиве зниження відчуття своєї психічної цілісності, безпосереднє, суб'єктивно сприймане відчуття крихкості особистості; переживання тривоги й почуття самітності при соціальній невдачі, тому такі особистості не завжди можуть використовувати соціум для свого екзистенційного захисту. Осмутнені особи часто відчувають інтенсивні депресивні переживання безглуздості, безцільності життя, малодушності, внутрішньої порожнечі, безсилля, безперспективності, від яких особистість не може захиститися (H1+ неспроможне Self). Ці люди багато в чому психологічно залежні від значущих осіб, від чужої, нехай навіть авторитетної думки, вони схильні драматизувати недотримання вірності з боку значущої особи й не знаходять опору в самому собі. Вони очікують стабільних відносин, гарантованих від розчарування й втрати, й, не одержуючи цього, включають «фантазію як захист від самітності, безпорадності й розпачу» (Н16+ симбіотичний захист Self) (Залуцкая, 2003; Корнилова, Корнилов, Чумакова \& Талмач, 2015).

Загалом, специфіку композиції нарцисичних параметрів у осіб, що різняться за емоційністю, можна пояснити, звертаючись до психологічної сутності кожної емоції. Відомо, що емоції різної якості відрізняються одна від одної відношенням до об'єкта, що виражається в знаку домінуючих 
емоцій (додатний знак «+» властивий емоціям паттерну Р, тобто «позитивним» емоціям, від’ємний знак «-» властивий емоціям Г, С, П, тобто «негативним»), спрямованістю (на об'єкт або від нього), способом взаємодії з ним (активним або пасивним). Якщо емоціям паттерна «радість» властиво позитивне ставлення до об'єкта, спрямованість на об'єкт і активна з ним взаємодія, то паттернам емоцій страху, суму, й почасти гніву - неприйняття об' єкту, спрямованість від нього й, переважно, пасивні способи взаємодії 3 ним. Отже, якість емоцій може визначати глобальні форми взаємодії 3 навколишньою дійсністю, із психічними явищами, а виходить, i 3 деякими властивостями особистості, у тому числі й з нарцисизмом.

Наприклад, як показують дані літератури й наші дані, значення емоції «радість» конкретизується в сигнальній і ресурсо зберігаючій функції. Як сигнальна емоція, радість $\epsilon$ індикатором успішного ходу задоволення потреб, сигналізує про благополуччя, оскільки характеризує почуття психологічного комфорту, виступає емоційним компонентом задоволеності. У людини виникає відчуття гармонії зі світом і більш цілісне бачення себе й навколишнього простору, загострюється сприйнятливість до дійсності, що й знижує і навіть виключає нарцисичні риси особистості (Меленчук, 2015; Санникова, 2003, 2018; Izard, 1971). У негативних емоцій з'являються протилежні тенденції (Рейковский, 1979; Ekman, Friesen \& Tomkins, 1971; Izard, 1971; Sannikova, Sannikov \& Husak, 2020).

\section{Висновки}

1. У психології індивідуальних відмінностей неклінічний нарцисизм розглядається як стабільна риса особистості, яка варіює в межах норми, що й впливає на особливості спілкування і успішність діяльності. Як підгрунтя для пошуку індивідуальних відмінностей у проявах нарцисизма обрана емоційність, яку, на відміну від розуміння її в «моделі особистості HEXACO» і в моделі особистості «Велика П'ятірка», розглядаємо як стійку схильність до домінуючого переживання емоцій певного знаку і модальності (якість емоцій).

2. Виявлено значущі кореляційні зв'язки між якісними показниками емоційності й спектром показників нарцисизма, що емпірично підтверджує теоретичні погляди на взаємовплив означених властивостей особистості. Отримані коефіцієнти кореляцій розділилися на два протилежних полюси: додатний, що охоплює значущі прямі взаємозв'язки показників нарцисизма $з$ модальностями Г (гнів), С (страх), П (сум) і від’ємний, який містить зворотні взаємозв'язки показників нарцисизма з показником емоційності Р (радість).

3. Із вибірки обстежених виділені групи осіб з різним типом емоційності (стійка схильність до переживань емоцій певного знаку й модальності). Розглянуті профілі нарцисизма й на цій основі досліджено його специфіку в представників мономодальних типів емоційності, встановлені відмінності в структурі й проявах неклінічного нарцисизма між представниками різних типів емоційності. Представникам групи Р (домінування радості) властивий оптимізм, віра у власні сили, можливість подолання кризи за рахунок мобілізації власних ресурсів, висока соціабельність, впевненість у собі й у своїй цінності. Особи, які схильні до переживання емоцій паттерна гнів мають високу самооцінку та віру в свою соціальну ефективність, прагнення до похвали, проте схильні до переживання образи, приниження, розчарування, прагнуть бути в центрі уваги. Для представників групи С (схильність до остраху), характерний стан безпорадності, негативна самооцінка, почуття власного безсилля, переживання страху, тривожність, соціальне уникнення з метою захисту від нарцисичної травматизації. Особам, які схильні до суму (представникам групи П), властиві бар'єри спілкування, депресивні переживання, схильність до самотності, вибірковість у виборі 
партнера, що дозволяє їм знаходити адекватну дистанцію в спілкуванні, відчуття безглуздості, безцільності життя, малодушності, безсилля, безперспективності. Загалом, специфіка композиції нарцисичних параметрів в осіб, що різняться за емоційністю, пояснюється психологічною сутністю кожної емоції. Доведено, що певному типу емоційності відповідає певна якісно-кількісна комбінація показників нарцисизма.

4. Показано, що нарцисичні тенденції більшою мірою супроводжуються негативними емоціями, у той час як модальність Р і емоції цього паттерна знижують, гальмують прояви цієї властивості. Встановлено, що індивідуальні відмінності за емоційністю характеризуються унікальною композицією елементів усього складу показників нарцисизма, ступенем їх інтегрованості, репертуарною різноманітністю можливих проявів.

Отже, як встановлено у дослідженнях емоційності, якість емоцій (модальність і знак) визначає глобальні форми взаємодії з навколишньою дійсністю, із психічними явищами, 3 нарцисизмом як складною властивістю особистості.

Перспективу подальших досліджень ми вбачаємо у вивченні індивідуальнопсихологічних особливостей «темної тріади» особистості (де нарцисизм $є$ одним із іiі компонентів) у осіб з різними властивостями емоційності.

\section{Література}

1. Гордієнко, I.О. (2017). Самоприйняття та нарцисизм: співвідношення показників. Матеріали Всеукраїнської науково-практичної конференції молодих учених та студентів «Проблеми сучасної психології особистості» (м. Одеса, 25-26 травня 2017). (Випуск 8, c.62-67). Одеса : ВМВ.

2. Егорова, М.С., \& Ситникова, М.А. (2014). Тёмная триада. Психологические исследования, $7(10)$.

3. Залуцкая, H.M. (2003). Индекс функиионирования Self-системы (на основе теста оценки нариисизма). Санкт Петербург : НИПНИ им. В.М. Бехтерева.

4. Клепикова, Н.М. (2011). Операциональное определение нарцисизма в пределах психической нормы. (Автореф. дис. канд. психол. наук). Хабаровск.

5. Корнилова, Т.В., Корнилов, С.А., Чумакова, М.А., \& Талмач, М.С. (2015). Методика диагностики личностных черт «Темной триады»: апробация опросника «Темная дюжина». Психологический журнал, 36(2), 99-112 . Издательский дом ВЭШ

6. Меленчук, Н.І. (2015). Нарцисичні прояви авантюрності. Наука і освіта, 10, 91-97. Одеса : ПНЦ НАПН України.

7. Меленчук, Н.I., \& Бєлєнцова, О.В. (2019). Нарцисизм як предиктор авантюрності особистості. Матеріали Всеукраӥнської наук.-практ. конф. «Проблеми сучасної психології особистості. Ресурси та чинники психологічного благополуччя особистості» (м. Одеса, 21 березня 2019 р). (с. 113-120.) Одеса : ВМВ.

8. Модель структуры личности НЕХАСО . Режим доступа: http://hexaco.org/scaledescriptions

9. Небылицын, В.Д. (2000). Проблемь психологии индивидуальности. А.В. Брушлинский и Т.Н. Ушакова. (Ред.).Москва : Московский психолого-социальный институт. Воронеж : Изд-во НПО «МОДЭК».

10. Ольшанникова, А.Е. (1978). К психодиагностике эмоциональности. Проблемь общей, возрастной и педагогической психологии. В.В. Давыдов (Ред.). 93-105 . Москва : «Педагогика»

11. Рейковский, Януш (1979). Экспериментальная психология эмоций. Москва : Прогресс. Режим доступа: http://vprosvet.ru/biblioteka/eksperimentalnaya-psihologiya-emocij

12. Саннікова, О.П. (2003). Науково-методичний твір «Психодиагностический четьрехмодальностный тест-опросник эмочииональности». Заявка № 8664 від 30.09.2003; реєстрац. № 8828 від 24.11.2003. 30 с. 
13. Саннікова, О.П. (2014). Емоційність як системна властивість особистості. III Всеукраїнський психологічний конгрес 3 міжннародною участю «Особистість у сучасному світі». (с. 77-82). Київ : ДП «Інформаційно-аналітичне агентство».

14. Саннікова, О.П. (2014). Континуально-ієрархічна модель емоційності. Наука $і$ освіта, 1(CXVIII), 44-50 .

15. Саннікова, О.П., \& Децик, М.П. (2018). Пошук індивідуальних відмінностей у проявах нарцисизма. Матеріали Всеукраїнської науково-практичної конференції молодих учених та студентів «Проблеми сучасної психологї особистості» (м. Одеса, 17-18 травня 2018 р.). (Випуск 9, с. 16-22 ). Одеса : ВМВ.

16. Фрейд, 3. (2006) О введении понятия «наричичиз». Психология бессознательного. Москва : СТД, 39-73.

17. Фромм, Э. (2010). Душа человека. Москва : АCT. Режим доступа: http://www.gumer.info/bibliotekBuks/Psihol/from/indexphp

18. Ekman, P., Friesen, W., \& Tomkins, S. (1971). Facial affect scoring technigues: a first validity studi. Semiotika, 3, 37-58. https://doi.org/10.1515/semi.1971.3.1.37

19. Izard, C.E. (1971). The face of emotion. New York : Appleton.

20. Jonason, P.K. Jones, K., \& Krause, L. (2013). The emotional deficits associated with the Dark Triad traits: Cognitive empathy, affective empathy, and alexithymia. Person. and Individ. Diff., $55,532-537$.

21. Jones, D.N., \& Paulhus, D.L. (2010). Different provocations trigger aggression in narcissists and psychopaths. Social Psychological and Personality Science, 1, 12-18 .

22. Morf, C.C. \& Rhodewalt, F. (2009). Die Paradoxa des Narzissmus ein dynamisches selbstregulatorisches Prozessmodell. Narzissmus Grundlagen - Störungsbilder - Therapie. Stuttgart-New York : Schattauer, 308-347.

23. Paulhus, D.L., \& Williams, K.M. (2002). The Dark Triad of personality: Narcissism, Machiavellianism, and Psychopathy. Journal of Research in Personality, 36, 556-563.

24. Sannikova, O.P., Sannikov, O.I., \& Husak, L.I. (2020). Features of decisiveness in individuals with different emotional disposition. Georgian Medical News, 4(301), 136-142.

25. Svindseth, M.F., Sorebo, O., Nottestad, J.A., Roaldset, J.O., Wallin, J., \& Dahl, A.A. (2009). Psychometric examination and normative data for the narcissistic personality inventory 29 item version. Scand. J. Psychol., 50(2), 151-159.

\section{References}

1. Hordiienko, I.O. (2017). Samopryiniattia ta nartsysyzm: spivvidnoshennia pokaznykiv [Selfperception and narcissism: correlation of concepts]. Materialy Vseukrainskoi naukovopraktychnoi konferentsii molodykh uchenykh ta studentiv «Problemy suchasnoi psykholohii osobystosti»-Proceedings of the All-Ukrainian scientific-practical conference of young scientists and students "Problems of modern personality psychology" (Odesa, May 25-26, 2017). (Issue 8, pp.62-67). Odesa : VMV [in Ukrainian].

2. Egorova, M.S., \& Sitnikova, M.A. (2014). Tjomnaja triada [The Dark Triad]. Psihologicheskie issledovanija - Psychological Studies, 7(10) [in Russian].

3. Zaluckaja, N.M. (2003). Indeks funkcionirovanija Self-sistemy (na osnove testa ocenki narcissizma) [The index of the Self-system functioning (based on the narcissism assessment test)]. Saint Petersburg : NIPNI im. V.M. Behtereva [in Russian].

4. Klepikova, N.M. (2011). Operacionalnoe opredelenie narcissizma v predelah psihicheskoj normy [The operational definition of narcissism within the psychic norm]. Extended abstract of candidate's thesis. Habarovsk [in Russian].

5. Kornilova, T.V., Kornilov, S.A., Chumakova, M.A., \& Talmach, M.S. (2015). Metodika diagnostiki lichnostnyh chert «Temnoj triady»: aprobacija oprosnika «Temnaja djuzhina» [The technique of diagnosing the personality traits of the "Dark Triad": approbation of the "Dark Dozen" questionnaire]. Psihologicheskij zhurnal - Psychological Journal, 36(2), 99-112 [in Russian]. 
6. Melenchuk, N.I. (2015). Nartsystychni proyavy avantiurnosti [Narcissistic manifestations of adventurism]. Nauka i osvita - Science and Education, 10, 91-97 [in Ukrainian].

7. Melenchuk, N.I., \& Bielientsova, O.V. (2019). Nartsysyzm yak predyktor avantiurnosti osobystosti [Narcissism as a predictor of individual's adventurism]. Materialy Vseukrainskoi naukovo-praktychnoi konferentsii "Problemy suchasnoi psykholohii osobystosti. Resursy ta chynnyky psykholohichnoho blahopoluchchia osobystosti» - Materials All-Ukrainian scientificpractical. conf. "Problemy suchasnoi psykholohii osobystosti. Resursy ta chynnyky psykholohichnoho blahopoluchchia osobystosti” (Odesa, March 21, 2019). (pp. 113-120.). Odesa : VMV [in Ukrainian].

8. Model struktury lichnosti HEXACO [HEXACO personality structure model] (2016). [Jelektronnyj resurs]. Retrieved from http://hexaco.org/scaledescriptions [in Russian].

9. Nebylicyn, V.D. (2000). Problemy psihologii individualnosti [Problems of personality psychology]. Brushlinskyi, A.V., \& Ushakova, T.N. (Eds.). Moscow : Moskovskij psihologosocialnyj institut; Voronezh : Izd-vo NPO «MODJeK» [in Russian].

10. Olshannikova, A.E. (1978). K psihodiagnostike jemocionalnosti [About psychodiagnostics of emotionality]. Problemy obshhej, vozrastnoj i pedagogicheskoj psihologii-Problems of general, age and pedagogical psychology, 93-105. Moscow [in Russian].

11. Reykovskiy, Yanush (1979). Eksperimentalnaya psihologiya emotsiy [Experimental psychology of emotions]. Moscow : Progres. Retrieved from http://vprosvet.ru/biblioteka/eksperimentalnayapsihologiya-emocij [in Russian].

12. Sannikova, O.P. (2003). Naukovo-metodichnij tvir «Psihodiagnosticheskij chetyrehmodalnostnyj test-oprosnik jemocionalnosti» [Scientific and methodical work «Psychodiagnostic four-modality emotionality test-questionnaire»]. Zaiavka № 8664 vid 30.09.2003; reiestrats. № 8828 vid 24.11.2003. 30 [in Ukrainian].

13. Sannikova, O.P. (2014). Emotsiinist yak systmena vlastyvist osobystosti [Emotionality as a systemic property of personality]. III Vseukrainskyi psykholohichnyi konhres z mizhnarodnoiu uchastiu "Osobystist u suchasnomu sviti» - III All-Ukrainian psychological congress with international participation "Personality in modern world", 77-82 [in Ukrainian].

14. Sannikova, O.P. (2014). Kontynualno-iierarkhichna model emotsiinosti [Continual and hierarchical model of emotionality]. Nauka i osvita - Science and Education, 1(CXVIII), 44-50 [in Ukrainian].

15. Sannikova, O.P., \& Detsyk, M.P. (2018). Poshuk indyvidualnykh vidminnostei u proiavakh nartsysyzmu [Search for individual differences in the manifestation of narcissim]. Issues of modern personality psychology. Proceedings of All-Ukrainian scientific and practical conference, of young scientists and students, 9, 16-22 [in Ukrainian].

16. Freid, Z. (2006). O vvedenii ponjatija «narcissizm». Psihologija bessoznatelnogo [On the introduction of the concept of "narcissism". Psychology of the unconscious]. Moscow : STD [in Russian].

17. Fromm, Je. (2010). Dusha cheloveka [The Soul of Man]. Moscow : AST. Retrieved from http://www.gumer.info/bibliotekBuks/Psihol/from/indexphp [in Russian].

18. Ekman, P., Friesen, W., \& Tomkins, S. (1971). Facial affect scoring techniques: a first validity study. Semiotika - Semiotics, 3, 37-58. https://doi.org/10.1515/semi.1971.3.1.37

19. Izard, C.E. (1971). The face of emotion. New York : Appleton.

20. Jonason, P., Jones, K., \& Krause, L. (2013). The emotional deficits associated with the Dark Triad traits: Cognitive empathy, affective empathy, and alexithymia. Person. and Individ. Diff., 55, 532-537.

21. Jones, D.N., \& Paulhus, D.L. (2010). Different provocations trigger aggression in narcissists and psychopaths. Social Psychological and Personality Science, 1, 12-18.

22. Morf, C.C., \& Rhodewalt, F. (2009). Die Paradoxa des Narzissmus ein dynamisches selbstregulatorisches Prozessmodell. Narzissmus Grundlagen - Störungsbilder - Therapie. Stuttgart - New York : Schattauer, 308-347.

23. Paulhus, D.L., \& Williams, K.M. (2002). The Dark Triad of personality: Narcissism, 
Machiavellianism, and Psychopathy. Journal of Research in Personality, 36, 556-563.

24. Sannikova, O.P., Sannikov, O.I., \& Husak, L.I. (2020). Features of decisiveness in individuals with different emotional disposition. Georgian Medical News, 4(301), 136-142.

25. Svindseth, M.F., Sorebo, O., Nottestad, J.A., Roaldset, J.O., Wallin, J., \& Dahl, A.A. (2009). Psychometric examination and normative data for the narcissistic personality inventory 29 item version. Scand J Psychol., 50(2), 151-159.

\author{
MANIFESTATIONS OF NON-CLINICAL NARCISSISM: \\ SEARCH FOR INDIVIDUAL DIFFERENCES \\ Olha Sannikova \\ Doctor of Scientes in Psychology, Professor, \\ Head of Department of General and Differential Psychology \\ State institution «South Ukrainian National Pedagogical \\ University named after K.D. Ushinsky» \\ 4, Fountain Road Str., Odessa, Ukraine, 65020 \\ osanniland@gmail.com, https://orcid.org/0000-0003-3961-2103 \\ Researcher ID: I-5139-2018
}

\begin{abstract}
The article is based on a longstanding professional experience of the author to identify the individual peculiarities of personality that are distinguished by their psychological emotionality. The author considers the specifics of some undesirable social manifestations relating to narcissistic tendencies, to extreme (subclinical) variants of "norm". "Free individualism" which has recently become popular in the society does not only lead to communication disorders, interpersonal relationships, affects the activity progress, but also puts ahead the development of the personal organization as a narcissistic one. That is why the theoretical and methodological substantiation of the problem of narcissism, the study of its psychological manifestations, individual variations of the signs of this phenomenon is becoming relevant. Emotionality has been chosen as the basis of the search for individually typical features of narcissism, which is considered as a purposive tendency to experience emotions of a certain quality (sign and modality of dominant emotions). The article is aimed to present and discuss the results of the study on individual psychological features of non-clinical narcissism in people who differ in emotionality. The presence of negative significant correlations between the emotional modality "Joy" and most indicators of narcissism is revealed, while such modalities as "Anger", "Fear", "Sadness" correlate with indicators of narcissism mostly positively. The author considers the profiles of narcissism among the persons who differ in emotionality (steady dominance of one of the emotional modalities); studies "psychological portraits" of people who are prone to narcissistic tendencies and its specifics in representatives of monomodal types of emotionality; establishes differences in the structure and manifestations of narcissism among the representatives of different types of emotions. It is proved that the individual originality of narcissistic traits within the mental norm, the variability of their individual compositions (qualitative-quantitative combination of narcissism components) are conditioned by the degree of dominance of a certain emotional modality. Keywords: narcissism, narcissistic tendencies, emotionality, individual-psychological compositions of narcissism.
\end{abstract}

